\title{
SENTANA RAJEG DAN NILAI ANAK LAKI-LAKI BAGI KOMUNITAS BALI DIASPORA DI KABUPATEN KONAWE
}

\author{
Yohanes Krismantyo Susanta \\ STAK Negeri Toraja \\ yohanessusanta@gmail.com
}

Artikel diterima 10 Desember 2018, diseleksi 18 Mei 2019, dan disetujui 25 Juni 2019

\begin{abstract}
Gender inequality is not something new, because women have long been treated unfairly and discriminatively in relation to their roles and positions. In this case, duties and responsibilities of a wife is to bear children, especially a son. This article aims to describe the changing of Balinese women diapora in Konawe using indepth interviews (indepth interview) with question guide. The results show those women still face discrimination and are required to have offspring especially sons. In the context of the Balinese society which prioritizes male role, the failure to have offspring is the fault of the women. In fact, religious and community leaders could minimize this gender injustice practices because there is also some religious norm and concept of sentana rajeg to back it.
\end{abstract}

Keywords: Balinese Women, Heredity, Infertility, Sentana Rajeg.

\begin{abstract}
Abstrak
Persoalan ketidakadilan gender yang dialami perempuan bukanlah sesuatu yang baru. Telah sejak lama perempuan diperlakukan tidak adil dan diskriminatif terkait peran dan kedudukannya. Demikian pula dalam hal tugas dan tanggung jawabnya sebagai seorang istri yang dituntut untuk melahirkan anak. Tulisan ini mendeksripsikan perempuan Bali yang berada di perantauan dalam menghadapi tuntutan untuk melahirkan anak laki-laki. Informasi diperoleh melalui wawancara mendalam (indepth interview) yang menggunakan panduan pertanyaan penelitian terhadap pasangan suami istri yang tidak punya anak. Kajian ini menunjukkan bahwa para perempuan di perantauan (Kabupaten Konawe) tetap mengalami diskriminasi dan dituntut untuk memiliki keturunan (anak laki-laki). Dalam konteks masyarakat Bali yang mengedepankan peran laki-laki, kegagalan memiliki keturunan adalah kesalahan pihak perempuan. Tokoh agama dan masyarakat mampu mengikis praktik ketidakadilan gender tersebut, karena adanya aturan agama dan lembaga Sentana Rajeg yang dapat digunakan.
\end{abstract}

Kata kunci: Perempuan Bali, Keturunan, Kemandulan, Sentana Rajeg. 


\section{PENDAHULUAN}

Budaya dan tradisi masyarakat Bali sangat dipengaruhi oleh agama Hindu, dengan demikian Hukum adat yang berlaku juga sarat dengan nilai-nilai yang diajarkan oleh agama tersebut. Ketika program transmigrasi dilaksanakan dan masyarakat Bali tersebar di seluruh wilayah Indonesia, biasanya mereka membentuk sebuah kampung bersama disebut kampung Bali. Masyarakat Bali di perantauan yang hidup bersama dalam satu kampung ternyata tetap memegang tradisi dan hukum adat yang selama ini dianut, tidak terkecuali masyarakat Bali di Sulawesi Tenggara. Agama yang dianut oleh masyarakat Bali di Sulawesi Tenggara adalah Hindu dan Kristen. Itu sebabnya sebuah pura atau gereja (baik Protestan maupun Katolik) mudah dijumpai di beberapa kampung Bali di Sulawesi Tenggara. Berdasarkan hasil wawancara dengan Mertha seorang pemuka adat setempat di kabupaten Konawe), seluruh anggota kampung tersebut diatur oleh peraturan dan hukum adat yang dibuat oleh para pemuka adat. ${ }^{1}$ Tulisan ini berdasarkan keberlangsungan praktik di masyarakat dengan menyoroti pemahaman tentang keturunan dan kemandulan yang masih bertahan di kalangan masyarakat Bali di perantauan tepatnya di kabupaten Konawe, Sulawesi Tenggara.

\section{METODE}

Tulisan ini menggambarkan persoalan yang terjadi dan dihadapi oleh keluarga Bali di perantauan, khususnya kaum perempuan terkait dengan persoalan seputar keturunan, kemandulan, dan ketidakadilan

1 Mertha, wawancara 20 dan 22 Desember 2016. terhadap perempuan. Deskripsi tersebut merupakan hasil penelitian atas sejumlah literatur dan hasil penelitian lapangan (wawancara). Penelitian ini menggunakan pendekatan kualitatif dengan melakukan wawancara mendalam dengan delapan belas pasangan suami-istri dari suku Bali yang dipilih secara acak (lima pasang di antaranya belum memiliki anak kandung dalam jangka waktu lama, antara lima sampai delapan tahun), empat orang tokoh adat, dan 5 orang tokoh agama (Hindu dan Kristen). Penelitian bertujuan melihat pergumulan riil yang dihadapi perempuan dalam konteks budaya Bali yang menekankan pentingnya keturunan (laki-laki) serta melihat sejauh mana peran tokoh agama dan masyarakat dalam usaha mengikis ketidakadilan gender yang terjadi.

\section{PEMBAHASAN}

\section{Nilai Anak Dalam Kehidupan Sebagian Besar Suku di Indonesia}

Topik keturunan dan kemandulan bukanlah sesuatu yang baru khususnya dalam bidang kedokteran, antropologi, dan sosiologi. Misalnya, penelitian Tjok Istri Putra Astiti di desa Baturiti, kecamatan Tabanan Bali pada 1994 dalam disertasi berjudul Pengaruh Hukum Adat dan Program keluarga berencana terhadap Nilai Anak Laki-laki dan Perempuan pada Masyarakat Bali yang sedang Berubah (Astiti 1994) dan kemudian dituangkan dalam sebuah artikel berjudul "Nilai anak dalam kehidupan keluarga orang Bali" yang dimuat dalam buku bunga rampai Sosiologi Keluarga (Astiti 1999), menjelaskan tentang pemahaman masyarakat Bali yang mengutamakan anak laki-laki dibanding anak perempuan. Akibatnya, jika anak pertama atau anak kedua berjenis kelamin perempuan,

\begin{tabular}{l|l} 
Jurnal Multikultural \& Multireligius Vol. 17 & No.2
\end{tabular} 
maka keluarga tersebut akan berusaha menambah keturunan (anak), dengan harapanbahwa anakyanglahirselanjutnya berjenis kelamin laki-laki. Sementara itu topik tentang pentingnya kehadiran seorang anak dalam kehidupan keluarga dapat ditemui dalam penelitian Harahap dan Siahaan yang melihat arti pentingnya seorang anak dalam kehidupan masyarakat Batak Toba (Harahap dan Siahaan, 1987: 136). Selanjutnya, penelitian Ihromi juga memperlihatkan bahwa kehadiran keturunan atau anak juga sangat penting bagi suku Toraja yang lekat dengan tradisi tongkonannya, baik sebagai tanda persekutuan sesama turunan nenek maupun terkait dengan pelaksanaan upacara rambusolo (Ihromi, 1981: 111-116).

Sementara itu, menurut ilmu kesehatan atau kedokteran, kemandulan merupakan suatu kondisi kesulitan memiliki anak yang ditandai dengan ketidakmampuan mengandung atau melahirkan janin dengan selamat, dalam kurun waktu satu tahun kalender. Kemandulan tersebut juga meliputi keguguran (miscarriage), janin meninggal, atau kelahiran mati (stillbirth) (Feske, 2012: 31). Jelas bahwa kemandulan adalah sebuah persoalan dalam budaya yang menekankan pentingnya nilai serta kehadiran seorang anak. Bahkan menurut Astiti sebagaimana dikutip oleh Yohanes Krismantyo Susanta, pada sebuah momen resepsi pernikahan, acapkali para undangan yang hadir akan mengucapkan kalimat berisi harapan: "cepat dapat momongan,ya." Tak hanya itu,keluarga dan anak menjadi topik pembicaraan ketika dua sahabat lama bertemu (Susanta, 2017: 250). Hal ini sekali lagi memberikan bukti bahwa secara sosiologis, kehadiran anak merupakan sesuatu yang penting, bahkan seringkali dianggap sebagai salah satu tujuan dari pernikahan.

\section{Pemahaman Budaya Bali tentang Keturunan}

Menurut Astiti, nilai seorang anak bagi orangtua dapat diketahui antara lain dari adanya kenyataan bahwa anak menjadi tempat orangtua mencurahkan kasih sayang, anak merupakan sumber kebahagiaan keluarga, anak seringkali dijadikan pertimbangan oleh suamiistri untuk membatalkan keinginan bercerai, kepada anak nilai-nilai dalam keluarga disosialisasikan dan harta kekayaan keluarga diwariskan, dan anak juga menjadi tempat orangtua menggantungkan berbagai harapan (Astiti, 1999: 226-227). Selain itu, secara khusus, di keluarga Bali, mempunyai anak sangat penting karena hal tersebut dianggap menjadi salah satu cara membayar hutang kepada orangtua, karena dengan mempunyai anak, barulah segala macam kesulitan dan penderitaan yang pernah dialami orangtua dapat dirasakan.

Bagi masyarakat Bali, yang paling penting bukan sekadar mempunyai anak, melainkan juga seorang cucu. Hal tersebut didasari oleh keyakinan yang berkembang bahwa cucu tersebut, kelak menolong sang kakek mencapai Surga atau nirwana (, pemahaman yang pengaruhi tradisi Hindu. Hal tersebut tampak dalam ungkapan "I cucu nyupat I kaki" (cucunya menyelamatkan kakeknya) (Astiti, 1994: 37). Mitos Jaratkaru juga memperkuat keyakinan ini. Di dalam mitos tersebut diceritakan tentang Jaratkaru yang bertemu leluhurnya yang hampir jatuh ke neraka. Arwah leluhurnya berkata kepada Jaratkaru: 
Beginilah akibatnya saya terputus dengan dunia atman. Kini saya tergantung pada sebilah bambu, hampir jatuh ke neraka. Adanya sebilah bambu ini karena saya sebenarnya mempunyai seorang keturunan. Jaratkaru namanya, tetapi ia berkeinginan untuk tidak kawin (cukla brahmacari).

Mendengar hal tersebut, Jaratkaru menjawab:

Ada jalan bagi tuan pergi ke surga. Janganlah ragu dan takut, hamba akan berhenti menjalankan cukla brahmacari. Hamba akan kawin dan memperoleh anak. (Astiti, 1999: 229).

Cerita tersebut memperlihatkan bahwa keturunan memainkan peran penting dalam kehidupan orangtua baik di dunia maupun di akhirat. Hal ini berarti, bagi masyarakat Bali, mendapatkan keturunan adalah penting. Oleh karena itu, tidak mengherankan jika setiap pasangan dalam keluarga Bali berharap segera memperoleh keturunan setelah menjalani hidup sebagai pasangan suami-istri.

Bagi masyarakat Bali, seorang anak laki-laki memegang peran yang sangat penting dibanding anak perempuan. Dengan demikian, persoalannya tidak berhenti pada keturunan yang akan dilahirkan melainkan berlanjut pada jenis kelamin anak yang juga turut diperhitungkan. Anak laki-laki bertanggung jawab mengurus orangtua ketika mereka tidak lagi mampu untuk bekerja serta melaksanakan hukum adat. Akan tetapi mereka diberikan hak berupa warisan sedangkan anak perempuan tidak berhak mendapatkannya karena setelah menikah ia akan masuk ke dalam ikatan keluarga suaminya dan dilepaskan dari tanggung jawab seperti yang dibebankan kepada anak laki-laki (Astiti, 1994: 273).

Senada dengan penelitian Astiti di atas, penelitian terhadap pasangan suami-istri Bali di kabupaten Konawe menunjukkan bahwa sebagian besar pasangan suami-istri mengakui bahwa sebutan ayah dan ibu terdengar lebih membahagiakan bagi mereka. ${ }^{2}$ Di samping itu, terdapat pasangan yang mengatakan bahwa mereka merasa sia-sia mengumpulkan banyak uang jika tidak memiliki keturunan. ${ }^{3}$ Hal tersebut menunjukkan bahwa selain karena tuntutan adat, memiliki anak juga merupakan kepuasan psikologis bagi pasangan suami-istri. Hal lain yang tak kalah menarik, dari 18 pasangan suami istriyang diwawancarai, semuanya (100\%) menjawab bahwa tujuan perkawinan adalah untuk memperoleh anak untuk menyambung garis keturunan dan menjalankan mandat dari Tuhan. Hasil penelitian ini juga menemukan beberapa alasan keluarga yang belum memiliki keturunan namun tidak melakukan pengobatan misalnya karena merasa malu untuk konsultasi ke dokter, tidak mempunyai biaya untuk berobat, baik secara medis maupun tradisional, kurang mendapatkan informasi dari pihak-pihak terkait untuk melakukan cek kesehatan reproduksi bagi pasangan suami-istri. ${ }^{4}$

Pasangan Bali yang telah lama

2 KP dan MS, wawancara 6 Januari 2017.

3 KPs dan GRS, wawancara 20 dan 22 Desember 2016.

4 Aris Tonapa (pendeta) dan Nyoman Suparmini, wawancara 17 dan 20 Desember 2016.

Jurnal Multikultural \& Multireligius Vol. 17 $\mid$ No.2 
menikah namun belum memiliki anak biasanya menempuh pengobatan alternatif atau tradisional dengan harapan akan segera memiliki keturunan. Menurut penuturan seorang pemangku adat Bali di desa Olooloho, kabupaten Konawe, pasangan suamiistri yang belum mempunyai anak dapat melaksanakan nunas pejati (nunas adalah permohonan kepada leluhur sedangkan pejati adalah nama jenis sesajen yang diberikan). Menurut Mertha, "Biasanya, keluarga yang melaksanakan ritual ini adalah keluarga yang sudah pernah ke dokter tetapi belum menemukan solusi. Atau bisa juga keluarga yang ingin berobat ke dokter tetapi karena belum ada biaya, terpaksa memakai cara tradisional tersebut." ${ }^{5}$ Kegiatan ini dilakukan secara tertutup dan hanya dihadiri oleh keluarga atau kerabat dekat dari pasangan suamiistri tersebut.

Selain itu, salah satu solusi yang dapat ditempuh oleh keluarga Bali yang tidak memiliki anak adalah dengan mengangkat anak (meras sentana). ${ }^{6}$ Pengertian pengangkatan anak menurut hukum adat Bali yaitu mengangkat anak orang lain dan menempatkannya sebagai anak kandung dengan tujuan melanjutkan keturunan dari kapurusa (putera utama). Itu sebabnya, syarat mutlak adalah anak yang diangkat berjenis kelamin laki-laki. Pertimbangan yang digunakan ketika mengangkat anak adalah garis keturunan dan silsilah yang jelas. Masyarakat Bali menganut sistem kekeluargaan patrilineal, yaitu berdasar pada garis keturunan bapak. Sistem kekelurgaan tersebut membuat peran seorang anak laki-laki sangat penting sebagai penerus keturunan bagi keluarganya.

5 Mertha, wawancara 20 dan 22 Desember 2016.

6 Mertha, wawancara 20 dan 22 Desember 2016.
Sementara itu, bagi keluarga yang hanya memiliki anak perempuan, solusi atas masalah tersebut adalah menjadikan anak perempuan sebagai sentana rajeg, yakni diberi status sebagai laki-laki untuk melanjutkan garis keturunan ayahnya dan hal tersebut sudah diatur dalam undang-undang. ${ }^{7}$ Status tersebut diberikan ketika anak perempuan akan menikah. Perkawinan tersebut dikenal pula sebagai kawin nyeburin atau nikah sentana yaitu mempelai laki-laki masuk ke kerabat istri dengan berkedudukan sebagai perempuan dan mempelai perempuan tetap tinggal di kerabatnya sendiri dengan status sebagai laki-laki (Astiti, 1999: 230).

Menurut penelitian Astiti, keinginan memiliki anak bagi orang Bali terkait dengan nilai anak yang dikategorikan dari berbagai segi yaitu segi religius, sosial, ekonomi, dan psikologis. Pertama, anak dari sudut pandangan religius mempunyai nilai yang dilandasi oleh adanya prinsip hutang secara timbal balik antara orang tua dan anak. Seorang anak dapat membayar hutang orangtuanya kepada leluhur (Astiti, 1999: 237-238). Kedua, Kedudukan anak laki-laki lebih tinggi dari anak perempuan. Masyarakat Bali yang dipengaruhi sistem patrilineal menetapkan bahwa warisan diteruskan melalui garis keturunan laki-laki. Aturan pewarisan ini secara umum diatur dalam hukum adat dan secara khusus diatur dalam awig-awig (aturan) banjar (desa) masing-masing (Astiti, 1999: 234235). Ketiga, dari sudut ekonomi anak

7 Keputusan Mahkamah Agung no. 358/sip/1971 mengatakan bahwa seorang pria Bali bernama N.K. yang kawin sentana dengan almarhum N.R. dinyatakan tidak berhak lagi untuk tinggal di rumah mendiang "suaminya" karena N.K yang dalam hal ini berkedudukan sebagai "janda" menyalahi dharmanya sebagai janda karena tanpa izin keluarga terdekat almarhum suaminya, kawin lagi (Ihromi, 1981: 111). 
berperan untuk memberikan bantuan baik berupa tenaga maupun materi. Bantuan tersebut dilandasi adanya kewajiban, sedangkan bantuan yang diberikan anak perempuan hanya bersifat sukarela (Astiti, 1999: 237). Keempat, kelak seorang anak dapat menggantikan orangtua dalam melaksanakan kegiatan adat di lingkungan kerabat maupun masyarakat. Selain itu, anak dirasakan dapat menghibur orangtua, memberi dorongan untuk lebih maju, dan bertahan dalam situasi sulit (Astiti, 1999: 237). Menurut Astiti, keempat segi tersebut menyebabkan masyarakat Bali, lebih mengharapkan anak laki-laki daripada anak perempuan.

Hasil penelitian Astiti tersebut juga dapat dijumpai kemiripannya pada warga Olooloho yang mayoritas berasal dari suku Bali. Warga desa Olooloho sebagian besar bekerja sebagai petani. Menurut beberapa orang warga, selain alasan budaya atau adat, kehadiran seorang anak dalam keluarga dapat membantu pekerjaan mereka (alasan praktis). Hal itu disampaikan MS:

Anak-anak bisa membantu pekerjaan kami untuk ngangon (menggembalakan) sapiatau bekerja di sawah. Anak-anak laki-laki juga bisa ngarit (mencari rumput) sedangkan anak perempuan bisa membantu pekerjaan ibunya di rumah. $^{8}$

Para orangtua di desa membiasakan anak mereka untuk membantu bekerja baik di sawah milik keluarga sendiri maupun bekerja dengan mendapatkan upah dari orang lain. Hal

8 MS, wawancara 18 Desember 2016. Hal yang senada juga dikemukakan oleh WN dan KD, wawancara 4 Januari 2017. tersebut dengan mudah dapat dijumpai dari pengalaman hidup sehari-hari masyarakat desa Olooloho. Anak-anak yang duduk di bangku Sekolah Dasar sudah terbiasa dengan pekerjaan seperti memandikan sapi, mencari rumput untuk makanan sapi, membuat perapian di sekitar kandang ternak pada malam hari, menggembalakan ternak seperti sapi, kambing dan itik. Selain itu, mereka juga bisa membantu perekonomian orangtua dengan cara memancing ikan di rawa atau memasang bubuh (perangkap ikan). ${ }^{9}$ Pekerjaan tersebut tidak hanya dilakukan oleh anak laki-laki tetapi juga oleh anak perempuan. Akan tetapi, pada umumnya, pekerjaan anak perempuan adalah di rumah, membantu kegiatan di dapur termasuk mengolah pakan ternak. Dengan demikian, tampaknya, bagi masyarakat desa Olooloho, kehadiran seorang anak juga sangat penting dalam membantu meringankan masalah perekonomian rumah tangga dengan cara membantu pekerjaan orang tua mereka sebagai petani.

\section{Pemahaman Budaya Bali tentang Kemandulan}

Dalam budaya Bali, keluarga yang tidak memiliki anak dipandang sebagai keluarga yang rugi atau tidak beruntung. Sebagaimana telah disebutkan dalam bagian pendahuluan, sebuah julukan diberikan kepada pasangan suami-istri tersebut dalam bahasa Bali, yaitu: Nang Pocol dan Men Pocol atau Nang Bekung dan Men Bekung (pocol berarti rugi, sedangkan bekung berarti mandul. Nang berarti ayahnya sedangkan Men berarti ibunya) (Astiti, 1999: 227). Hal tersebut berarti kemandulan dianggap sebagai hal yang negatif dan tak seorangpun yang

9 Putu Suastika, wawancara 19 Desember 2016. \begin{tabular}{l|l} 
Jurnal Multikultural \& Multireligius Vol. 17 & No. 2
\end{tabular} 
ingin berada dalam situasi tersebut. Hal itu juga diperlihatkan oleh pasangan suami-istri MD. Sang suami mengatakan:

Saya terkadang sampai menggugat Tuhan. Kenapa ada orang yang gampang memiliki anak, anaknya sampai sepuluh, sedangkan saya sudah berusaha kesana kemari tetapi tidak juga mendapatkannya. Padahal ada banyak orang menyianyiakan anaknya, ada yang dibuang dan digugurkan. Saya dapat satu saja sudah sangat bersyukur. ${ }^{10}$

Pandangan senada diungkapkan oleh Ibu PW yang merasa iri hati sekaligus putus asa karena belum memiliki anak meskipun telah mencoba berbagai cara.

Saya sering merasa iri ketika melihat ibu-ibu menggendong anak kandungnya. Kapan ya saya bisa juga menggendong anak sendiri? Kadang-kadang juga stres karena sudah ke sana kemari tetapi belum juga bisa punya anak. ${ }^{11}$

Sementara itu, bagi keluarga KP, memiliki keturunan bukanlah persoalan utama bagi mereka secara pribadi. Akan tetapi, tuntutan lingkungan dan keluarga dekatlah yang membuat mereka merasa terbebani dan berusaha untuk segera memiliki anak.

Saya dan istri sebenarnya tidak terlalu mempersoalkan mempunyai anak atau tidak. Tetapi kami sering merasa risih jika orang bertanya tentang anak. Padahal kami sudah pernah ke dokter dan kata dokter, saya dan istri

10 MD, wawancara 18 Desember 2016. Hal yang miris terjadi di sini. Sebab, dalam pengakuannya, MD mengatakan sulit memiliki anak, padahal ia memiliki anak perempuan. Tampaknya, anak yang dimaksud adalah anak laki-laki.

11 PW, wawancara 21 Desember 2016. Keluarga PW telah mengangkat anak (meras sentana) tetapi masih menantikan kehadiran anak kandung.

HARMONI Juli - Desember 2018 tidak ada masalah, tidak mandul. Jadi ya, pasrah saja kepada Tuhan. Mungkin memang belum waktunya atau belum rejekinya. Kita tunggu saja. ${ }^{12}$

Pendapat menarik terkait persoalan keturunan dan kemandulan dikemukakan oleh WN. Menurutnya, tidak ada orang yang mandul. Pandangannya tersebut dipengaruhi oleh pengalaman keluarga WN yang telah menikah selama 15 tahun tetapi belum memiliki keturunan. Berbagai usaha telah mereka lakukan (baik medis maupun tradisional) sampai pada satu titik mereka menerima keadaan tanpa anak tersebut. Akan tetapi setelah 15 tahun menjalani pernikahan, Tuhan memberikan mereka seorang anak (saat ini keluarga $\mathrm{WN}$ telah dikaruniai tiga orang anak). Pengalaman tersebut membuat keluarga WN tiba pada kesimpulan bahwa tidak ada orang yang mandul jika Tuhan sendiri yang berkenan memberikan anak sesuai dengan waktu Tuhan. ${ }^{13}$

Di dalam budaya Bali, kemandulan dapat menjadi salah satu faktor penyebab terjadinya perceraian. Meskipun masyarakat Bali menekankan pentingnya anak, khususnya anak laki-laki, akan tetapi hukum adat saat ini melarang keras praktik poligami bagi keluarga yang tidak memiliki keturunan. Itu sebabnya, pengangkatan anak (meras sentana) atau kawin nyeburin menjadi alternatif sekaligus usaha mencegah terjadinya poligami. Namun, hukum adat justru memberikan kelonggaran dan mengizinkan perceraian, karena alasan

12 KP, wawancara 19 Desember 2016. Seperti halnya keluarga PW, keluarga KP juga sudah melaksanakan meras sentana.

13 WN, wawancara 4 Januari 2017. 
tidak memperoleh keturunan. ${ }^{14}$

Hal tersebut juga diperparah dengan kurangnya peran tokoh agama (Kristen dan Hindu) dalam memberikan pengertian yang benar dari sudut pandang keagamaan mengenai hakikat perkawinan dan masalah keturunan. Beberapa tokoh masyarakat yang ada beralasan bahwa persoalan kemandulan adalah masalah yang sangat sensitif dalam kehidupan keluarga. ${ }^{15}$

\section{Pemahaman Budaya Bali tentang Perempuan}

Menurut van Eck yang mengutip Gedong Bagoes Oka, seorang perempuan setelah menikah berfungsi untuk menjaga, menghuni, dan memelihara dua dunia yaitu dunia keluarga (domestik) dan dunia di luar keluarga (publik) (van Eck, 1994: 65). Seorang istri dituntut untuk "pandai merawat, melayani suami dengan baik dan penuh kepasrahan, membangun atmosfir rumah menjadi teduh dan aman, serta menjaga nama baik keluarganya" (van Eck, 1994: 65). Dalam beberapa kasus - akibat sistem budaya Bali yang menekankan dominasi lakilaki - sering terjadi, seorang istri wajib berjuang sendirian untuk menghidupi keluarganya dan tetap menerima keadaan suaminya. Bahkan, kadang kala suami seenaknya menghabiskan waktu dengan bermain tajen atau adu ayam, sementara sang istri bekerja dengan keras (van Eck, 1994: 75).

Kendati demikian, hal yang menarik, hukum adat Bali ternyata juga berisi aturan yang sangat positif dalam menghargai peran dan kedudukan

14 Mertha, wawancara 20 dan 22 Desember 2016.

15 I Made Garden Panca, wawancara 21 Desember 2016. perempuan. Akan tetapi teks-teks tersebut mengalami pengabaian dan cenderung dilupakan, misalnya yang tertulis dalam Manawa Dharmacastra III sloka 58:

Bagi setiap keluarga yang tidak menghormati kaum perempuan, niscaya keluarga itu akan hancur lebur berantakan. Rumah di mana perempuannya tidak dihormati sewajarnya, mengungkapkan kutukan, keluarga itu akan hancur seluruhnya, seolah-olah dihancurkan oleh kekuatan gaib. (Whedariyadnya, 2000: 99).

Dalam sloka Madawa Dharmasastra III: 59 juga diatur dan disebutkan tentang tanggung jawab atau kewajiban suami kepada istrinya sebagai berikut: "Oleh karena itu, orang (suami) yang ingin sejahtera, wajib selalu menghormati wanita, pada hari raya dengan memberi hadiah, perhiasan, pakaian, dan makanan" (Bali Post Website 2016).

Aturan yang tertulis dalam hukum adat tersebut menunjukkan bahwa sesungguhnya hukum adat Bali sangat menghormati perempuan. Akan tetapi dalam praktiknya, hal tersebut tidak terlaksana. Tampaknya, kondisi ideal (penghormatan kepada perempuan) yang tertuang dalam hukum adat tidak sejalan dengan kondisi faktual yang terjadi di tengah masyarakat. Dalam kondisi demikian, seorang perempuan Bali dituntut untuk dapat melaksanakan perannya sebagai seorang istri sekaligus seorang ibu yang mampu melahirkan anak-anak untuk menyambung garis keturunan keluarga.

Masyarakat Bali memiliki bias patriarkat yang sangat kental. Hal tersebut

\begin{tabular}{l|l} 
Jurnal Multikultural \& Multireligius Vol. 17 & No. 2
\end{tabular} 
membawa implikasi pula terhadap peran reproduksi biologis dan reproduksi sosial perempuan Bali. Menurut Luh Putu Sendratari, peran reproduksi sosial perempuan meliputi pekerjaan domestik seperti memasak, menyetrika pakaian, mengatur keuangan agar keluarga, dan memberi tempat yang nyaman agar suami dan anak-anak yang sudah bekerja bisa bekerja kembali keesokan harinya (Bali Post Website 2016). Dalam hubungannya dengan ini, ada beberapa jargon yang mencerminkan bahwa peran perempuan tersebut dianggap sepele karena hanya mengurus pekerjaan rumah yang dianggap tidak menghasilkan uang, misalnya sebutan pengayah (pelayan) bagi perempuan yang telah menikah terhadap suami dan keluarganya. Sebutan lain yang tidak kalah meremehkan adalah sebutan tetekan (pendatang tanpa sumber daya) bagi perempuan di rumah keluarga suaminya (Bali Post Website 2016). Bagaimana dengan peran reproduksi perempuan Bali? Menurut Sendratari, "dalam menjalankan peran reproduksi biologis, seorang perempuan Bali yang terbungkus dalam ideologi patriarki memiliki kecemasan dalam menunggu kelahiran seorang anak" (Bali Post Website 2016).

Menurut penelitian Suharni, kemandulan menjadi salah satu pemicu terjadinya ketidakharmonisan dalam rumah tangga, perceraian atau pengucilan dalam masyarakat dan perempuan menjadi pihak yang seringkali menjadi korban(Suharni, 1997:21). Hasil penelitian Hull dan Tukiran juga memberikan kesan yang kuat terhadap masalah tersebut. Penelitian Hull dan Tukiran mengenai kemandulan di Indonesia menghasilkan lima kesimpulan, yaitu:

Pertama, perempuan yang HARMONI Juli - Desember 2018 mandul memiliki potensi atau berkemungkinan untuk dicerai atau dimadu. Kedua, perempuan tersebut akan distigmatisasi. Ketiga, perempuan yang mandul mempunyai kesulitan menemukan fullfill role di dalam komunitasnya sehingga menghalangi meningkatkan mobilitas sosialnya. Keempat, pasangan mandul menghabiskan banyak waktu dan biaya dalam upaya menemukan "perawatan" bagi kondisi mereka. Kelima, kasus kemandulan bisa menjadi sumber "rasa malu" pada perempuan yang telah kawin. (Hull dan Tukiran, 1976: 88-116).

Menurut Mertha, dalam budaya Bali, apabila terjadi perceraian, maka istri yang diceraikan akan kembali ke keluarga asalnya, dan beralih menjadi tanggungjawab orangtua atau saudara laki-lakinya. Hak asuh anak jatuh pada suami atau keluarga suaminya, sehingga perempuan tersebut tidak memiliki tanggung jawab kepada anakanaknya tersebut. Hal itu berarti ketika perceraian terjadi, maka perempuan Bali akan kehilangan segalanya dalam pengertian tidak mendapat warisan dan harta bersama dalam perkawinan, tidak mendapat hak asuh anak, bahkan wajib menghidupi dirinya sendiri. Ketimpangan tersebut juga tampak jelas. Misalnya, di satu sisi, seorang suami dengan mudah dapat mengajukan cerai hanya karena sang istri tidak dapat melahirkan anak, tetapi di sisi lain, seorang istri dalam keluarga Bali kemungkinan kesulitan atau tidak berani mengajukan cerai karena takut kehilangan haknya meskipun ia mengalami tekanan dan kekerasan dalam rumah tangga (KDRT).

Masalah perceraian di Indonesia 
diatur dalam Undang-undang Nomor 1 tahun 1974 tentang Perkawinan, salah satu bunyi ayat dari undang-undang tersebut menyebutkan syarat terjadinya perceraian adalah "salah satu pihak mendapat cacat badan atau penyakit dengan akibat tidak dapat menjalankan kewajibannya sebagai suami-istri." Ayat ini seringkali dipakai sebagai dasar untuk menceraikan istri karena dianggap tidak dapat menjalankan kewajiban memberikan anak (Suharni, 1997: 19). Dampak lanjutan dari perceraian yang terjadi adalah pemberian label oleh masyarakat bagi pasangan yang bercerai, duda dan janda. Label janda dan duda sebenarnya memiliki nilai yang sama secara sosial, namun secara budaya konotasi "janda" akibat perceraian selalu berkonotasi negatif di mata masyarakat (Suharni, 1997: 20).

Tidak hanya itu, pengalaman pahit perempuan Bali yang tidak memiliki anak atau hanya memiliki anak perempuan dituangkan secara terbuka oleh Ida Ayu Made Gayatri dalam tulisan berjudul, Sisi Gelap Kekerasan Ideologi Patriarki pada Perempuan Bali. Menurut Gayatri, perempuan yang telah menikah namun tidak memiliki anak,dianggap tidak sempurna dan disebut baki (wandu), sang mandul. Jika suaminya meninggal lebih dulu, keluarga suami akan berusaha menyingkirkannya dengan berbagai strategi (Bali Post Website 2016).

Sementara itu, perempuan yang menikah tetapi tidak mempunyai anak laki-laki juga dianggap kurang sempurna. Perempuan yang hanya memiliki anak perempuan tidak jarang mendapat tekanan dari keluarga dan lingkungan sosial untuk melahirkan bayi laki-laki. ${ }^{16}$

16 Temuan yang sama juga ditemukan dalam penelitian lapangan sebagaimana yang dikemukakan
"Rahimnya dijadikan mesin pencetak bayi laki-laki. Jika mesin itu gagal, maka para orangtua cenderung untuk menekan anak perempuannya untuk mencari sentana ketika anak gadisnya beranjak dewasa" (Bali Post Website 2016). Dengan demikian, eksistensi keluarga perempuan tetap dapat dipertahankan dalam silsilah keluarganya. "Jika tidak, niscaya keluarga lain seperti sepupu dan paman mereka akan melakukan ekspansi kekuasaan untuk mengambil alih warisan keluarga" (Bali Post Website 2016).

Sementara itu, perkawinan nyentana tidak serta merta menyelesaikan persoalan dalam kehidupan keluarga Bali. Hal tersebut juga ditunjukkan oleh penelitian Gayatri.

Laki-laki nyentana bisa jadi mendapat tekanan sosial karena perubahan "status gender" menjadi "perempuan" dianggap rendah oleh keluarganya sendiri atau oleh lingkungannya yang baru. Tampaknya konsep ini telah terdistorsi begitu jauh. Lelaki yang menikah dengan cara nyentana sesungguhnya menjalankan kewajibannya sebagai kepala keluarga sama seperti keluarga lainnya. Hanya saja kewajiban itu tidak dilaksanakan di rumah keluarga batihnya, melainkan dilakukan pada keluarga istrinya. Lelaki inilah yang mewakili istrinya sebagai kepala keluarga dan menggunakan haknya di lingkungan di mana mereka tinggal. Akan tetapi dalam praktiknya, lelaki nyentana sering direndahkan dan dijuluki "paid bangkung'" (diseret oleh babi betina), sebuah ungkapan kasar

oleh Mertha, pemangku adat setempat.

\begin{tabular}{l|l} 
Jurnal Multikultural \& Multireligius Vol. 17 & No. 2
\end{tabular} 
dan merendahkan. Akibatnya, lakilaki nyentana tersebut cenderung bertingkah apatis. Misalnya, memilih untuk tidak bekerja, tidak melakukan apapun dan menjadikan semua itu sebagai kewajiban istri dan keluarga barunya. (Bali Post Website 2016)

Fakta-fakta tersebut memperlihatkan bahwa dalam budaya Bali, lahir sebagai anak perempuan di tengah keluarga yang tidak memiliki anak laki-laki menjadi risiko tersendiri. Anak perempuan atau istri dari perkawinan ini mengalami berbagai ketidakadilan dan kekerasan mulai dari tekanan keluarga dan tekanan sosial, bahkan kekerasan dalam rumah tangganya sendiri.

\section{Peran Tokoh Agama dan Masyarakat dalam Mengikis Ketidakadilan Gender}

Ketiadaan anak atau kemandulan yang dialami sebuah keluarga menjadi salah satu situasi dari banyak situasi yang menindas perempuan. Oleh karena itu diperlukan usaha dan kerja keras dari setiap elemen masyarakat khususnya peran dari tokoh agama dan masyarakat setempat agar praktik diskriminasi dalam kehidupan berumah tangga khususnya yang terkait dengan masalah keturunan bisa dicegah dan dikikis perlahan-lahan.

Beberapa pemahaman yang perlu diberikan baik oleh tokoh agama maupun masyarakat Bali di kabupaten Konawe antara lain mengajak warga masyarakat untuk memahami ulang hakikat dan tujuan perkawinan; memahami ulang makna kehadiran anak dalam perkawinan; memahami ulang peran dan kedudukan perempuan sebagai upaya mengikis ketidakadilan gender.

\section{Memahami Ulang Hakikat dan Tujuan Perkawinan}

Perkawinan melegitimasi persatuan antara dua pribadi yang berbeda, laki-laki dan perempuan. Dalam tataran norma serta kebiasaan yang berlaku dalam masyarakat, perkawinan merupakan lembaga yang memungkinkan lahirnya anak-anak atau keturunan. Hal itu berarti, persoalan tentang keturunan berkaitan dengan cara pandang masyarakat tentang hakikat dan tujuan sebuah perkawinan. Sebagaimana telah disebutkan, bagi masyarakat Bali, tujuan perkawinan adalah untuk memperoleh keturunan. Pemahaman yang berkembang tersebut membuat setiap keluarga an berusaha melakukan apa pun untuk segera memperoleh keturunan. Dalam beberapa kasus, seorang istri diceraikan oleh suami karena alasan tidak memiliki keturunan. Pemahaman yang sempit tentang hakikat dan tujuan perkawinan tersebut dapat dikoreksi.

Dalam hukum adat Bali, perkawinan dipandang sebagai wiwaha yaitu "ikatan suci dan komitmen seumur hidup menjadi suami-istri. Laki-laki dan perempuan adalah belahan jiwa yang melalui ikatan pernikahan dipersatukan kembali agar menjadi manusia yang seutuhnya karena di antara keduanya dapat saling mengisi dan memperlengkapi" (Bali Post Website 2016). Hal tersebut menunjukkan bahwa perkawinan merupakan wadah bagi suami-istri untuk saling berbagi dan menikmati kebahagiaan, bukan sematamata untuk memperoleh keturunan. Pemahaman tersebut memiliki kontribusi positif sekaligus kritik terhadap budaya Bali yang mengizinkan terjadinya perceraian dalam perkawinan dengan alasan tidak memiliki anak. Pemahaman tersebut sangat dangkal dan membuat 
hakikat perkawinan sebagai penyatuan antara dua pribadi mengalami degradasi makna sehingga mudah diputuskan hanya karena tidak adanya anak. Sayangnya, hukum adat Bali masih mengizinkan terjadinya perceraian dengan alasan karena tidak memiliki anak. Meskipun ada upaya pencegahan melalui lembaga pengangkatan anak, tetapi hukum adat Bali tampaknya merestui perceraian jika keluarga tersebut, dalam hal ini suami, bersikeras untuk memiliki anak kandung serta menolak untuk mengangkat anak.

\section{Memahami Ulang Makna Kehadiran Anak dalam Perkawinan}

Ada banyak kasus kekerasan yang menimpa anak-anak dan tak jarang hal tersebut terjadi dalam keluarga atau dilakukan oleh orang terdekat. Data Komisi Perlindungan Anak Indonesia (KPAI) pada Januari-Agustus 2012 mencatat terdapat 3332 kasus kekerasan terhadap anak di Indonesia. Sayangnya dari data tersebut, keluarga menjadi tempat terbanyak terjadinya kekerasan terhadap anak, yakni sebanyak 496 kasus, menyusul dalam bidang pendidikan, yakni mencapai 470 kasus (Kompas Website 2016).

Terkait dengan statistik di atas, pengakuan akan pentingnya seorang anak dalam budaya Bali bermakna amat positif. Itu sebabnya, sangat jarang terjadi, keluarga Bali menelantarkan anak mereka sendiri. Anak-anak dijaga dan dipelihara, tidak boleh ditelantarkan, tidak boleh disia-siakan (Bali Post Website 2016). Budaya tersebut merupakan sesuatu yang dapat dipertahankan karena sarat dengan nilai-nilai positif sekaligus menjadi masukan yang berharga. Sayangnya, hal tersebut masih sarat dengan diskriminasi sebab meskipun nilai seorang anak dalam budaya Bali sangat penting tetapi masih terbatas pada anak laki-laki.

Salah satu teks dalam budaya Bali yang dapat dijadikan pintu masuk untuk merekonstruksi paham tersebut terdapat dalam Manawa Darmacastra IX: 96, "Tidak ada perbedaan putra lakilaki dengan putra perempuan, baik yang berhubungan dengan masalah duniawi ataupun masalah kewajiban suci. Karena bagi ayah dan ibu mereka keduanya lahir dari badan yang sama" (Whedariyadnya, 2000: 100). Hal ini berarti pemahaman yang lebih mengutamakan anak lakilaki dibandingkan anak perempuan sebenarnya dapat dikikis dan ditinggalkan perlahan-lahan. ${ }^{17}$

\section{Memahami Ulang Peran dan Kedudukan Perempuan Sebagai Upaya Mengikis Ketidakadilan Gender}

Keluarga Bali lebih menginginkan seorang anak laki-laki daripada anak perempuan untuk meneruskan garis keturunan bapak berdasar pada sistem kekeluargaan patrilineal. Anak perempuan dalam keluarga Balijuga tidak mendapat warisan keluarga. Seorang anak perempuan dapat memperoleh warisan hanya jika tidak ada laki-laki dalam keluarga tersebut dan ketika akan menikah, ia akan menjalani perkawinan sentana, diberi status sebagai laki-laki dan suaminya diberi status sebagai perempuan. ${ }^{18}$

17 Dalam mitos Jaratkaru juga disebutkan leluhur tidak mencapai nirwana karena tidak ada keturunan. Mitos tersebut tidak mengatakan bahwa keturunan lakilaki lebih penting daripada perempuan.

18 Hal tersebut juga diketahui oleh warga Olooloho, INY, NES dan WPR, wawancara 21 Desember 2016 dan 5 Januari 2017.

\begin{tabular}{l|l} 
Jurnal Multikultural \& Multireligius Vol. 17 & No. 2
\end{tabular} 
Meskipun hukum adat Bali menyediakan solusi bagi yang tidak memiliki anak laki-laki yaitu lembaga sentana rajeg, tetapi hal tersebut tetap meninggalkan persoalan. Anak perempuan yang berkedudukan sebagai sentana rajeg sudah tentu berbeda dengan kedudukan anak perempuan pada umumnya. Hal ini berarti bahwa tradisi yang menindas dan meminggirkan perempuan telah ada dalam masyarakat Bali. Sistem kekeluargaan patrilineal yang dianut oleh masyarakat Bali memang diduga kuat memberi peluang suburnya budaya patriarkat (kekuasaan/dominasi laki-laki). Saat ini, aturan terkait masalah warisan kepada anak perempuan sudah sedikit melunak yaitu perbandingan warisan antara anak laki-laki dan perempuan adalah 2:1. ${ }^{19}$

Hal yang menarik, ditemukan bahwa hukum adat Bali ternyata berisi aturan yang sangat positif dalam menghargai peran dan kedudukan perempuan. Akan tetapi teks-teks demikian mengalami pengabaian dan cenderung dilupakan, misalnya yang tertulis dalam Manawa Dharmacastra IX: 96: "Tidak ada perbedaan putra lakilaki dengan putra perempuan, baik yang berhubungan dengan masalah duniawi ataupun masalah kewajiban suci. Karena bagi ayah dan ibu mereka keduanya lahir dari badan yang sama" (Whedariyadnya, 2000: 100).

Selanjutnya, Manawa Dharmacastra III. sloka 58 mengatakan:

Bagi setiap keluarga yang tidak menghormati kaum perempuan, niscaya keluarga itu akan hancur lebur berantakan. Rumah di mana perempuannya tidak dihormati

19 Mertha, wawancara 20 dan 22 Desember 2016. sewajarnya, mengungkapkan kutukan, keluarga itu akan hancur seluruhnya, seolah-olah dihancurkan oleh kekuatan gaib. (Whedariyadnya, 2000: 99)

Dari teks tersebut terlihat bahwa seorang perempuan dalam budaya Bali merupakan pihak yang dihormati dan dihargai serta memiliki tempat dan kedudukan yang sama seperti laki-laki. Pengabaian atas hal tersebut diyakini akan mendatangkan bencana. Hal ini berarti bahwa usaha dalam mengikis bias gender dalam kehidupan keluarga Bali dapat dimulai dari hukum adat tertulis itu sendiri.

Keinginan memperoleh keturunan atau anak tidak bisa hanya dibebankan kepada kepada kaum perempuan, karena tidak ada perempuan yang mengandung tanpa laki-laki. Reproduksi manusia membutuhkan tubuh perempuan. Fakta tersebut seharusnya membuat laki-laki dapat menghargai dan menghormati perempuan serta mensyukuri kehadirannya sebagai anugerah Tuhan yang diberikan untuk menjadi teman, mitra, istri, dan penolong yang sepadan.

Hal ini sekaligus memperlihatkan bahwa atau gambaran ideal mengenai peran dan kedudukan laki-laki dan perempuan sesungguhnya dapat dijumpai dalam budaya Bali dan tradisi keagamaan (Kristen dan Hindu) yang dianut masyarakat Bali di Konawe. Akan tetapi, tampaknya memang terdapat ketegangan antara gambaran atau konsep yang ideal dengan praktik yang terjadi (keadaan faktual). Praktik budaya (keadaan faktual) yang terjadi dalam keluarga Bali sering jauh dari konsep atau gambaran ideal. Untuk mengikis praktik yang keliru tersebut agar kembali kepada 
konsep yang ideal tentunya tidak mudah. "Kekerasan terhadap perempuan tidak akan terjadi dengan mudah seandainya tak ada anggapan bahwa perempuan makhluk yang lemah, makhluk kelas dua, diciptakan lebih rendah dari laki-laki" (Karman, 2004: 70). Sebab kenyataannya, "perempuan dan laki-laki semartabat dan berdiri sama tinggi. Konsep demikian harus terus dimasyarakatkan" (Karman, 2004: 70).

\section{SIMPULAN}

Kehadiran keturunan dalam sebuah keluarga dianggap sebagai sumber kebahagiaan suami-istri. Hal yang sama dapat dijumpai pada budaya Bali yang menekankan pentingnya anak sebagai penyambung garis keturunan dan sebagai pemelihara hukum adat. Bahkan terdapat kesinambungan pemahaman keagamaan pada komunitas Bali di Konawe. Hal ini menunjukkan bahwa ketiadaan anak dalam sebuah rumah tangga menjadi persoalan serius. Berbagai usaha dilakukan oleh pasangan suami-istri untuk dapat keluar dari situasi yang mungkin tidak pernah mereka pikirkan sebelumnya. Paham keturunan bersumber dari pemahaman masyarakat tentang konsep perkawinan. Pemaknaan ulang terhadap hakikat dan tujuan perkawinan memperlihatkan bahwa perkawinan merupakan perwujudan dari penyatuan laki-laki dan perempuan untuk memperoleh kepenuhan dan kebahagiaan hidup seperti yang dirancangkan oleh Sang Pencipta. Dengan demikian, tujuan perkawinan tidak boleh dipahami secara sempit untuk memperoleh keturunan.
Selanjutnya, relasi dominasisubordinasi antara laki-laki dan perempuan dapat ditafsirkan ulang. Budaya Bali sendiri ternyata memiliki penilaian dan pandangan yang positif terhadap perempuan. Konsep yang ideal, bahwa laki-laki dan perempuan memiliki kedudukan yang sama, dapat terus didengungkan dan dimasyarakatkan. Dengan demikian diskriminasi terhadap perempuan termasuk dalam hal tanggung jawab reproduksi dapat dikoreksi. untuk mewujudkannya maka diperlukan peran serta tokoh agama masyarakat supaya pemahaman yang meminggirkan kaum perempuan bisa dikikis perlahan, sebaliknya pemahaman yang menghormati perempuan sekaligus menjunjung tinggi nilai-nilai kemanusiaan seperti kesetaraan dan keadilan harus dimasyarakatkan.

\section{UCAPAN TERIMA KASIH}

Di akhir tulisan ini, penulis sangat berterima kasih kepada pimpinan STAK Negeri Toraja, baik di tingkat fakultas maupun universitas, yang telah memberikan kesempatan kepada penulis untuk melakukan penelitian tentang isu yang diangkat dalam tulisan ini, juga beberapa pihak dan informan yang terlibat dalam penggalian data dan informasi di dalamnya. Tidak ketinggalan, terima kasih juga penulis tujukan kepada Mitra Bestari dan Pengelola Jurnal Harmoni yang telah memberikan catatan dan saran untuk perbaikan tulisan ini, hingga bisa diterbitkan pada Jurnal Harmoni edisi kali ini. 


\section{DAFTAR ACUAN}

Astiti, Tjok Istri Putra. 1999. Nilai anak dalam kehidupan keluarga orang Bali. Dalam Bunga rampai sosiologi keluarga, peny. T. O. Ihromi, 226-238. Jakarta: Yayasan Obor Indonesia, 1999.

Harahap, Basyral Hamidy dan Hotman Siahaan. 1987. Orientasi nilai-nilai budaya Batak Toba: Suatu pendekatan terhadap perilaku Batak Toba dan Angkola-Mandailing. Jakarta: Sanggar Willem Iskandar.

Ihromi, T. O. 1981. Adat perkawinan Toraja Sa'dan dan tempatnya dalam hukum positif. Jakarta: Gadjah Mada University Press dan Yayasan Obor Indonesia.

Karman, Yonky. 2004. Bunga Rampai Teologi Perjanjian Lama. Jakarta: BPK Gunung Mulia

Suharni. 1997. Dampak infertilitas terhadap hubungan sosial dan ketahanan keluarga pada masyarakat Palembang. Yogyakarta: Pusat Penelitian Kependudukan UGM.

van Eck, R. 1994. Nasib kaum wanita di Bali. Dalam Peranan dan kedudukan wanita Indonesia, peny. Maria Ulfah S. dan T.O Ihromi, 58-79. Yogyakarta: UGM Press.

Whedariyadnya. 2000. Wanita, moral dan pembangunan. Bali: Pusat Studi Wanita Universitas Udayana.

Abdullah, Irwan. 1995. Reproduksi ketimpangan gender: Partisipasi wanita dalam kegiatan ekonomi. Prisma Vol. 24 No. 6 (tanpa bulan): 3-14.

Feske, Millicent C. 2012. Rachel's lament: The impact of infertility and pregnancy loss upon the religious faith of ordinary christians. The Journal of Pastoral Theology 22 (tanpa bulan): 1-17.

Hull, Terence. H. dan Tukiran. 1976. Regional variations in the prevalence of childlessness in Indonesia. The Indonesian Journal of Geography Vol. 6 No. 32 (tanpa bulan): 1-26.

Susanta, Yohanes Krismantyo. "“Barrenness": Jalan Penggenapan Janji Allah Bagi Keluarga Allah." Jurnal Jaffray15.2 (2017): 249-262.

Astiti, Tjok Istri Putra. 1994. Pengaruh hukum adat dan program keluarga berencana terhadap nilai anak laki-laki dan perempuan pada masyarakat Bali yang sedang berubah. Disertasi, Institut Pertanian Bogor.

Ida Ayu Made Gayatri, Sisi Gelap Kekerasan Ideologi Patriarki pada perempuan Bali. https://www.balipost.com/2011/02/01/sisi-gelap-kekerasan-ideologi-patriaki-padaperempuan-bali/ (diakses 27 Februari 2016).

Kompas. KPAI: Kekerasan Pada Anak Terbanyak Di Keluarga.

http://nasional.kompas.com/read/2012/09/11/21482667/

(diakses 18 November 2016).

Luh Putu Sendratari, Resistensi Perempuan Bali dalam Keberagaman. http:/www. balipost.com/Forum/178267/message/1025746743/Resistensi+Perempuan+Bali+dalam +Keberagaman (diakses 18 Januari 2016). 